\title{
РОЛЬ ІНФОРМАЦІЙНИХ ТЕХНОЛОГІЙ ПРИ ЗАСТОСУВАННІ МЕДИЧНИХ СТАНДАРТІВ
}

\author{
М. В. Голубчиков, О. С. Коваленко \\ Міністерство охорони здоров'я України \\ Міжнародний науково-навчальний центр інформаційних технологій та систем НАН і МОН \\ України
}

Підвищення рівня надання медичної допомоги прямо пов'язано із запровадженням медичних стандартів. Сучасний стан охорони здоров'я в Україні характеризується зростаючою необхідністю підвищення якості надання медичної допомоги на фоні хронічного дефіциту коштів на охорону здоров'я. Така ситуація вимагає розробки медичних стандартів та відповідних критеріїв для оцінки результатів наданої допомоги та проведення заходів, спрямованих на ефективне використання виділених коштів. Таким чином, головним завданням для системи охорони здоров'я є досягнення хороших результатів лікування пацієнтів при мінімальних витратах. Інформація, що отримується при здійсненні оцінки результатів медичного обслуговування і заходів, пов'язаних 3 визначенням ступеня задоволеності пацієнтів, а також витрат, які відповідають результатам лікування, важлива для всіх, хто пов' язаний з охороною здоров'я населення. Це, насамперед, медичні заклади та установи, фахівці, які зацікавлені у цьому процесі. Така інформація необхідна пацієнтам та їх лікарям у момент прийняття ними рішень щодо стратегії лікування та ії реалізації, вона корисна споживачам послуг, які повинні уміти вибирати кваліфікованих надавачів якісних медичних послуг.

При запровадженні медичних стандартів інформація про їх використання та якість надання медичної допомоги повинна надходити на всі рівні системи охорони здоров'я для здійснення відповідного контролю 3 боку адміністративних органів, страхових компаній чи спеціальних агенцій, які займаються цими питаннями.

Як відомо, медичні стандарти - це комплекс заходів, норм, правил і вимог, розроблених на основі наукових досліджень та оформлених у вигляді нормативно-технологічних документів, які затверджуються компетентним органом. У перелік цих документів входять:

- клінічні рекомендації (стандарти ведення хворих) - систематично розроблені документи, які описують дії лікаря з діагностики, профілактики та лікування захворювання. Вони відрізняються від традиційних

(с) М. В. Голубчиков, О. С. Коваленко джерел інформації тим, що розроблені за спеціальною методологією, грунтуються на доказовій медицині і регулярно оновлюються. Сьогодні клінічні рекомендації займають центральне місце в управлінні якістю медичної допомоги;

- клінічний протокол медичної організації-нормативний документ, який визначає вимоги до надання медичної допомоги хворому при певному захворюванні, з певним синдромом чи при певній клінічній ситуації у медичному закладі;

- алгоритми - схематично представлені дії лікаря при роботі з пацієнтом з певним захворюванням;

- лист індикаторів якості - документ, де фіксуються відхилення від виконання медичного стандарту при наданні медичної допомоги пацієнту лікарем.

Сам процес впровадження медичних стандартів супроводжується низкою заходів, які включають визначення місця впровадження (лікувальний заклад), навчання лікарського складу користуванню стандартами, розробку клінічних протоколів лікувального закладу, вбудовування текстів медичних стандартів в інформаційно-програмне забезпечення, що підтримує діяльність лікаря на робочому місці, формування інформаційної підсистеми контролю за виконанням стандартів, тобто контролю якості.

На сьогодні в Україні працює Проект Євросоюзу «Підтримка впровадження медичних стандартів в Україні», основною метою якого $є$ відпрацювання методології впровадження медичних стандартів.

Інформатизація процесу запровадження медичних стандартів включає, насамперед, формування підсистем збирання медичних даних, їх зберігання та оцінювання. Задачі інформатизації полягають у наступному.

- Інтегрування в прикладні програми модулів підтримки функціонування медичних стандартів на основі національних рекомендацій щодо змісту даних, спільних інтерфейсів, наборів кодів та загальних інформаційних послуг;

- Підтримка управління системою контролю якості надання медичних послуг на основі медичних стандартів із застосуванням сучасних методів аналізу якості, формування звітів; 
- Управління мережевими послугами на основі єдиного інформаційного трафіку, мережі та механізмів контролю за використанням мережі;

- Організація міжрегіонального обміну інформацією та даними для реалізації принципу єдиного медичного інформаційного простору при запровадженні медичних стандартів;

Виходячи з вищенаведеного можна прийти до висновку, що інформаційна система, яка повинна підтримувати процес застосування медичних стандартів, складається з кількох рівнів. Щоб уявити ії структуру, розглянемо процес надання медичної допомоги при їх застосуванні та документопотік який його супроводжує.

Як відомо, в Україні на первинному рівні надання медичної допомоги лікар веде прийом пацієнтів в амбулаторно-поліклінічному закладі. При цьому основним обліковим документом, з яким він працює, $є$ $\Phi-25 \backslash$ - Карта амбулаторного хворого. Саме в цьому документі фіксуються медичні відомості про пацієнта, його обстеження та лікування.

Медичні дані про пацієнта, що лікується у стаціонарі, вносяться до Ф-003 $\$ - Медична карта стаціонарного хворого. Ці два документи є основними обліковими формами, які застосовують у медичній практиці.

Далі дані, які знаходяться у цих документах, надходять до кабінетів медичної статистики, де здійснюється їх обробка, систематизація, аналіз та формування цілого переліку звітів державної статистичної звітності, звітності регіонального характеру та внутрішьолікарняної звітності. Після цього інтегрована інформація про діяльність медичних закладів, стан здоров'я населення регіону надходять до відповідних адміністративних рівнів охорони здоров'я.

Не зупиняючись на етапах впровадження медичних стандартів, розглянемо роботу медичного закладу в умовах їх застосування.

Клінічні рекомендації, що розробляються на національному рівні й у формуванні яких беруть участь провідні вчені-медики, стають основою для закладів охорони здоров'я, де безпосередньо здійснюється медична допомога, при створенні клінічних протоколів медичного закладу. Як вже зазначалося, клінічні протоколи створюються з метою нормативного забезпечення системи управління якістю медичної допомоги у закладі.

Клінічний протокол медичної установи розробляється для розв'язання наступних задач:

-вибір оптимальних технологій профілактики, діагностики, лікування і реабілітації для конкретного хворого; -захист прав пацієнта і лікаря при розв'язанні спірних і конфліктних питань;

-проведення експертизи і оцінки якості медичної допомоги хворим з певним захворюванням, синдромом чи в певній клінічній ситуації, і планування заходів 3 його удосконалення;

-планування обсягів медичної допомоги;

-розрахунок необхідних витрат на надання медичної допомоги;

-обгрунтування програми державних гарантій надання медичної допомоги населенню.

Для здійснення таких завдань необхідне відповідне інформаційно-програмне забезпечення. Такі програмні засоби повинні забезпечувати реалізацію низки завдань підтримки роботи лікаря на робочому місці і контролю якості надання медичної допомоги.

На нашу думку, на робочому місці лікаря повинно бути установлено програмне забезпечення, яке не тільки допомагає лікарю здійснювати свої прямі обов'язки, але також відкриває йому можливість користуватися національними клінічними рекомендаціями з даних нозологій, застосовуючи IНТЕРНЕТ-технологіі, клінічними протокалами, які розташовані у регіональній базі даних медичних документів чи базі даних медичного закладу. Для цього на рівні медичного закладу створюється локальна комп'ютерна мережа та формується відповідна база даних документів.

Часто-густо на районному рівні відсутнє деяке медичне устаткування чи клінічні методики, які визначені в медичних стандартах. Для проведення відповідних досліджень пацієнт може бути направлений до іншого лікувального закладу, де ці методики чи устаткування працюють. В таких випадках дані про результати досліджень повинні надходити з цих установ до даного лікувального закладу. При цьому використовуються канали зв'язку, які функціонують у регіоні, а така інформація повинна надходити до електронного медичного документа і вноситися у його структуру. Фіксація проведення певного дослідження в терміни, що вказані у медичних стандартах, дозволить оцінювати рівень якості наданої медичної допомоги.

Як вже зазначалося, одним з основних завдань при впровадженні клінічних протоколів, є завдання проведення контролю виконання стандартів надання медичної допомоги. Для цього запроваджуються спеціальні Листи індикаторів якості. Зміст такого листа включає кілька розділів, в яких відображаються основні медичні послуги, що характеризують виконання певного медичного стандарту. Заповнення та- 
кого листа індикаторів якості здійснює лікар. У випадку невиконання будь-якої процедури він зазначає причину невиконання. Таким чином, на кожний випадок надання медичної допомоги формуються Листи індикаторів якості.

Заповнення таких листів теж можна здійснювати за допомогою інформаційної системи. Для цього у самій системі формується формалізований опис медичних процедур, що їх призначає лікар, а також формалізований опис роботи самого лікаря. Як тільки лікар заповнює певні блоки електронного медичного документа, автоматично відповідні дані переносяться до Листів індикаторів якості. Те, що не можна перенести автоматично, лікар заповнює самостійно. I при закритті медичного документа, тобто при закінченні певного випадку медичного обслуговування, формується і відповідний Лист індикаторів якості.

Ці дані надходять до відповідної бази даних, а працівники кабінету медичної статистики формують відповідні звіти, які містять аналіз виконання медичних стандартів (для даного медичного закладу клінічних протоколів).

Окремим напрямком обробки результатів виконання медичних стандартів за допомогою Листів індикаторів якості $є$ автоматизована оцінка цих результатів. Відповідно до задач проекту розробляється структура звітності, яка відображає кількісні та якісні характеристики виконання медичних стандартів лікарським складом даного медичного закладу, всього закладу, групи закладів даного регіону тощо. Ці дані повинен аналізувати спеціаліст-аналітик. Спеціаліст-аналітик даних повинен розуміти сутність проведення лікувального процесу за результатами лікування, рівень використання інформації про медичні стандарти, перспективи лікарів та адміністрації і можливості потенціального використання даних. Ось чому при аналізі отриманих даних необхідно мати справу з достовірною інформацією, яку можна обро- бити за допомогою сучасних методів статистичного аналізу.

Аналіз даних потребує проведення статистичної експертизи; інтерпретація результатів потребує проведення клінічної експертизи. Але більшість лікарів та керівників охорони здоров'я мало розуміються в інтерпретації статистичної інформації. Ось чому аналітичні звіти повинні бути представлені у зрозумілому для них вигляді - у формі таблиць чи графіків.

Інформаційно-програмні засоби повинні відпрацьовувати ці функції та допомагати формувати відповідну звітність.

Звітні дані по локальній мережі регулярно повинні надходити до керівництва лікарні, а в разі потреби передаватися до управління охорони здоров'я даного регіону. Для цього використовуються канали зв'язку з цими установами.

На рівні управління охороною здоров'я має формуватися блок звітів, що стосується результатів управління якістю надання медичної допомоги до вищестоячих органів охорони здоров'я.

Отже, інформаційна система для підтримки роботи лікаря в умовах впровадження медичних стандартів повинна мати мережеву структуру для обміну даними між медичними закладами одного регіону, передачі звітних форм в установи управління охороною здоров'я.

На вищі рівні управлінської ланки галузі інформація повинна надходити згідно з регламентом, що встановлюється цими установами і у тому вигляді, як буде установлено.

Виходячи з вищенаведеного можна зробити наступний висновок-інформатизація процесу вповадження та підтримки медичних стандартів в Україні, з одного боку, допоможе здійснювати контроль за їх дотриманням, з іншого - підвищить ефективність роботи лікаря, що також відобразиться на рівні надання медичної допомоги. 